\title{
Proceeding
}

Supplementary Issue: Winter Conferences of Sports Science. Costa Blanca Sports Science Events, 22-23 March 2021. Alicante, Spain.

\section{The effect of sponsorships and product marketing on the management activities of football clubs: $A$ contextual and dimensional study}

\author{
GHAZWAN AZIZ MOHSEN $\triangle$, AMER RASHID SHAYYAL, MUSTAFA MOHAMMED ALI FARHAN \\ College of Physical Education and Sports Science, Wasit University, Iraq
}

\begin{abstract}
Market and marketing is important in our lives, as each of us looks forward to getting our different needs from the available resources, which are usually different and multiple. Therefore, different economic interests, producers of goods, services and ideas, strive to reach consumers and persuade them to buy goods and services, which they produce only. Marketing is not limited to the process of selling and advertising goods; it involves providing the required goods in the right place, at the right time and at the right price. Marketing is therefore one of the core activities of modern businesses. It is also a strategic hub, because it is a confrontation between the institution and the environment in which it is located.
\end{abstract}

Keywords: Marketing; Producers; Economic interest; Business; Football.

Cite this article as:

Mohsen, G.A., Shayyal, A.R., \& Ali Farhan, M.M. (2021). The effect of sponsorships and product marketing on the management activities of football clubs: A contextual and dimensional study. Journal of Human Sport and Exercise, 16(3proc), S1457S1466. https://doi.org/10.14198/ihse.2021.16.Proc3.62

Corresponding author. College of Physical Education and Sports Science, Wasit University, Iraq.

E-mail: gamuhsin@uowasit.edu.gi

Abstract submitted to: Winter Conferences of Sports Science. Costa Blanca Sports Science Events, 22-23 March 2021. Alicante, Spain.

JOURNAL OF HUMAN SPORT \& EXERCISE ISSN 1988-5202.

(c) Faculty of Education. University of Alicante.

doi:10.14198/jhse.2021.16.Proc3.62 


\section{INTRODUCTION}

Marketing activity is the window through which the region views the environment, it is the first and main entity to monitor what is happening in the surrounding external environment of factors or variables affecting its activity (Omar Aqili, 1994).

The American Marketing Association defined it in 1985 as "the process of planning, implementing, pricing and promoting the necessary ideas, goods and services to complete the exchange process that satisfies the needs and desires of individuals, and achieves the objectives of organizations" (Al Sabah, 2010).

It may increase sales, help the organization grow and create the necessary financial resources; To stimulate the economic cycle of searching for and purchasing raw materials and recruiting workers well (Al-Qurbuti, 2001). So, this study is an attempt to answer the following questions:

- What is the role of marketing in achieving the aims of economic growth and prosperity?

- What kind of good and integrated marketing system?

- How does an applicant in any country promote their products well and appropriately?

- Will sports sponsorship marketing increase the volume of trade with other countries and make a profit?

- The survival and growth of business organizations and their continued economic activity in the business world depends mainly on the extent to which effective marketing regulatory units exist in their regulatory structures, capable of successfully marketing their products in the market; how successful is the marketing activity to a large extent determine scoring to the extent that its operations are successful in achieving their objectives?

\section{THE CONCEPT OF MARKETING AND SPORTS SPONSORSHIP}

\section{The concept of sport marketing}

Philip Kotler defined marketing as a human activity aimed at satisfying human needs and desires, through exchanges (Al-Qurbuti, 2001).

According to Stanton and Fairbell, who defined marketing as "a whole system of business activities, designed for the purpose of planning, pricing and promoting goods and services, that satisfy the needs and desires of current and prospective consumers" (Al-Qurbuti, 2001).

Accordingly, sport is now one of the most important activities that attract industrial companies; it is one of the most important marketing areas for which companies allocate large amounts of money in order to promote their goods.

Therefore, we believe that the sports field is one of the most important sectors that can be used in the marketing of industrial products, because of its great benefit, especially in the developed world, where the economic sectors contribute, including: industrial companies to support sports activities directly or indirectly; this contributed to the significant development of the sports achievement of the teams and teams of these countries, and therefore reflected in the increase in the proportion of practitioners of sports activities (Sari Ahmed \& Suha Adeeb). 


\section{The concept of sports sponsorship}

Sponsorship is defined as: "maintenance assistance or the like, to an activity, through a business, for the purpose of obtaining commercial objectives" (Sari Ahmed \& Suha Adeeb).

Others have defined them as: "Institutions, companies, associations: civil, government, or businesses, support sports activities, sports federations, or sports heroes, in all sports activities or tournamentstournaments- competitions: local, or international. This support is material or moral, with the aim of commercial advertising, commercial or political advertising, or depending on the purpose of such care, and this care is due to the areas of physical and sports education by upgrading the sports level and increasing the practice base for various sports activities" (Sari Ahmed \& Suha Adeeb).

Commercial sponsorship and access to this world began on a limited scale in the mid-1900s; however, the marketing and sponsorship of sports activities developed significantly in the second half of the current century, for example by commercially investing sponsorship, advertising and television broadcasting of sporting events (Samir, 1999).

In one hand, Sponsorship is expected to have a better future than others because of the growing interest in the media in better coverage of sports activities, and for a longer period, as individuals are increasingly interested in sports participation, or watching sports activities constantly. Sports regulators have also become more flexible about accepting participation in sports sponsorship.

On the other hand, there has been a growing interest in sports sponsorship, which represents companies playing a key role in the emergence, growth and development of sport with its various activities. Some athletes, especially professionals, such as football, require a lot of money to organize and continue. Corporate sponsorship of sports activities is also a sophisticated marketing tool that is distinguished from other united means of advertising at a relatively low cost, as this cost is influenced by the success of the sporting event to reach the target audience. Therefore, the number of viewers reached by the sporting event. Therefore, the media has a very important role to play in achieving the spread, and the visibility of the sporting event, particularly the television that enters the event into the centre of the house at the right hours (Raad Habib, 1994).

The sports company support activities comes from advertising, to market their products through sports events attended by thousands of viewers and transmitted by television screens through their local and satellite channels to a wide audience. Thus, a more efficient and less expensive marketing method will be achieved than other advertising and marketing methods.

Many industrial companies have adopted this concept since the turn of the century because they understand the importance of this advertising or advertising medium, in increasing their sales. On the other hand, the governing bodies of international and continental championships have begun to pay great attention to motivating these companies to place their advertisements during matches, and to use multiple advertising tools, such as stadium side panels, t-shirts and sports equipment (Al-Zugheer, 1998). Sponsorship is expected to have a good future for the following reasons:

1. Growing interest from the media to better cover sports activities, and for a longer period.

2. The increased interest of individuals in sports participation or watching sports activities.

3. Sports organizations have become more flexible towards accepting participation in sports sponsorship. 
4. Advertising agencies have become obliged to allocate budgets for commercial advertising, and at the urging of the client to participate in sports and other activities.

On the other hand, there has been a growing interest in sports sponsorship, through which companies play a key role in the emergence, growth and development of sport with its various activities, particularly some sports, particularly professional sports, which require large sums of money to organize and continue.

Based on all of the above, it is clear to us that corporate sponsorship of sports activities is a sophisticated and important marketing tool, distinguished from other united means of advertising at a relatively low cost, as this cost is influenced by the success of the event and sports participation, in reaching the target audience. Consequently, the number of viewers reached is very large, as a result of sporting events.

The concept of sports support by companies and economic institutions was defined as: "Financial assistance or similar, to a club or sports activities, through a business institution for the purpose of obtaining commercial objectives" (Al-Zugheer, 1998).

This is where the relationship between the sports organization lies in one of the ways in which the foundation's objectives are achieved and the financial resources of sport are developed. Accordingly, we find that the institutions and companies that organized sporting events have made imaginary profits because of the increased money paid by these institutions to sponsor the sporting event in order to advertise their products, particularly with the proliferation of satellite television channels, which help to spread the name of the products of companies and economic institutions, and their brands throughout the world (Saleh Al-Hanawi, 1984).

\section{EVENT SPONSORSHIPS}

\section{The concept of event sponsorship}

Gray pointed out that sporting events are built, organized and run by sports federations, but these clubs alone cannot organize these events because of the high financial cost they must provide to organize these events, because budgets do not allow for any important and significant sporting event. Therefore, it is necessary to cooperate with economic institutions and companies to sponsor these events< and then to market their products, including: either full sponsorship or partnership, or the purchase of a sporting event entirely, the latter with financial consequences: either by profit, or by loss to the owner of the sporting event (Abdel Ati, 2001).

All this is done in order to complete the marketing of sporting events, to display and sell the products of economic institutions, especially in important sporting events, which are very popular, and the emergence of star players in these sporting events, to facilitate the process of communication between products and the consumer sports public.

The marketing relationship of sporting events is often linked to other means, reaching the public with a wide and wide resonance, such as newspapers, radios, billboards. But it remains a big relationship with the television that the sports event industry needs, because it has a great influence on the mind and the tendencies of the public (consumers); it not only attracts the sporting audience; it affects all the different audiences.

The benefit of sport lies in the free television sports event, for the purpose of attracting the largest number of viewers, as well as to other funders from other economic companies. 
All of this will help increase the financial funding of sports clubs for publicity rights, through the media, especially television.

\section{Sports finance}

Sport always needs "financiers, especially sports clubs, so that these clubs can be run better and achieve significant results; in our view, there are few and small sources of funding for sports clubs, including" (Abdullah Al-Bahout, 2002):

1. Revenues of sports authorities: such as the Ministry of Youth and Sports.

2. Enter the games by selling tickets.

3. Donations and subsidies.

4. Commercial investment of the sports club facility.

5. The proceeds of the transfer of players.

6. Income from getting championships.

In order to create a truly professional system for sports clubs in their running and organization, they must rely primarily on sources of funding, from private or capital institutions and economic companies. Hence, it can be transformed into a professional club industry. These institutions also benefit from their payment of these funds, in order to achieve several strategic objectives, through which their commercial profits are increased, through (Ahmed Shibli, 2003):

1. Marketing its products in the sports sector.

2. Defamation of their products, especially if the matches are broadcast on television.

However, what is noted for most Arab clubs is that the sources of sports finance by private institutions and economic companies are not fully developed, because of the extreme importance that sport plays in the development and increase of profits of these companies, as well as the achievement of a prominent position of these companies within both national and international markets, as well as achieving other strategic objectives.

\section{The concept of contributing to the establishment of sports facilities}

The sports establishment is "the basis for any sporting activity: whether it is for practice or entertainment, and it has great importance and an active role: in terms of increasing the revenue and financial revenues of the club, for the facilities and associations of the sports establishment, such as renting shops, commercializing them, or partnering with private economic institutions" (Al-Shafei \& Abdel Moneim, 2002).

Therefore, the sports club alone cannot improve, modernize or construct the facilities of the facility, because of its limited financial resources, which require considerable funds to be completed and exploited.

Therefore, these clubs must look for financial resources from private economic institutions, to improve, modernize, or create; for example, the well-known Egyptian billionaire Al Fayed, the owner of London famous Marrods, has bought the majority of Tottenham's shares, spent more than $£ 50$ million to modernize his facility, and to exploit his facilities: such as shops. It also has the right to a percentage of benefits: such as television rights, as well as entry income to matches (Al-Shafei \& Abdel Moneim, 2002). 


\section{THE TYPES OF SPONSORING ECONOMIC COMPANIES}

\section{Corporation}

In this type of institutions "which are branched into several sections, organization or management and capital are distributed to more than one person, and the seeds of some have emerged since the Babylonian era (Hammurabi Law). The Arabs also have (the company of people), passing through the Greeks and Romans. With the development of capitalist economic activity, the expansion of geographical exploration, and after the 15th century, others were completed" (Wadi Adon, 1998).

Here, it should be noted that these companies can only provide conditions in accordance with commercial law, such as: providing satisfaction between partners, which includes the subject of the company's activity and the value of each partner's share of capital, and free of fallacy, fraud or coercion. It also requires a place for the company's activity or the subject of this activity, as it must be legitimate, not contrary to the regulations and public morals, in addition to the reason, which is the desire of the partners to make profits behind the establishment of the institution. These elements are accompanied by the necessary capacity for the possibility of acting partners, carrying out their duties and carrying out what may arise: damage, registration, publicity.... etc. (AL-Din Badawi \& Amiri, 1992).

\section{Partnerships}

These companies can be seen as reproducing a number of individual enterprises, allowing larger capital to be pooled. Thus, the occupation of the greatest area of economic activity (Al-Din Badawi, 1994).

\section{General partnership}

This company is one of the most important companies of persons, in which partners offer shares that may be equal to their values or vary from partner to partner, in value and in the nature of the share; While their commitment to the organization's duties towards its customers exceeds their shares to include their own property other than the shares provided, this is the most important advantage of this company (Wadi Adon, 1998).

The management and conduct of such companies may also be requested by a person or persons of a partner or a foreigner, so that the practice of conducting on behalf of a company with an independent legal personality, or in the name of a partner may be the name of a partner; with reference to the presence of his partners (someone and his partners), or with a particular brand name.

The company activity can be in all different economic sectors, without being contrary to the law, morality or public order. They are often small or medium-sized and partners earn a profit of their capital shares, at the same proportions as they bear the loss (Wadi Adon, 1998).

\section{Commandite vompany}

It is a company consisting of two parties: (joint partners); they are responsible for the company's debts as personally as they own, in addition to their shares in capital, and recommended partners; i.e., their liability is determined by the extent to their shares. Therefore, there are two types of Recommendation Company (Adel, 2007):

1. A regular recommendation company, as the partners assigned to it, they cannot in any way trade their shares.

2. A company that recommends shares, in which the shares of the shareholders take the nature of the shares; they are tradable. 
The company also does not, in any way, manage the company, and "its name does not appear in the company name, and by comparing the trustee with the debtor of that company, they are similar, but the former has no guarantee of what to offer in the capital; because it aims to participate, i.e. to divide profits and losses if they occur, while the trustee can obtain concessions through the mutual partners, such as: guarantee profits a fixed percentage, and the enterprise provides, even if it does not make real profits; it will bear it next years" (Wadi Adon, 1998).

\section{Joint venture}

"It is a business entity created by two or more parties, generally characterized by shared ownership, shared returns and risks, and shared governance. Companies typically pursue joint ventures for one of four reasons: to access a new market, particularly emerging markets; to gain scale efficiencies by combining assets and operations; to share risk for major investments or projects; or to access skills and capabilities".

In doing so, it organizes a special organization on the basis of the financial liability of the partners. If one of them is a manager, it is in his name "as if he were self-employed, others are limited to investing their money in the company's business. The company can be managed by a group of partners, or by an external person, and in all cases the manager (or managers) treats as if they are self-employed and do not mention the names of other companies" (Jamil Al-Rubadi, 2003).

\section{L.L.C Limited Liability Company}

It is a type of business entity in "private" ownership used in many jurisdictions, in contrast to "public" ownership, with some differences from country to country. The company is considered "less advanced for other species, having only appeared in the 19th century (1892), in German commercial law, and then introduced into French commercial law in 1925. The government position on the matter is that the government position on the matter is not to be dismissed" (Jamil Al-Rubadi, 2003).

According to commercial law in some countries, such as Iraq, these companies are established among partners who bear losses only within their quotas. This company is characterized by limited partner responsibility as much as the shares it offers, which are equal and non-negotiable. It also has limited capital, and "must not be less than a certain amount, divided into equal value shares, the minimum amount limited in state currency, the number of partners is limited, and acquisition is not carried out in its general form" (Wadi Adon, 1998).

The administration is by one or more partners, or by an external person, who performs the management work of the company, heads the association of partners that discusses the company's accounts and balance sheet, approves it, makes decisions that it deems necessary, and the vote shall be according to the number of shares in which it participates (Wadi Adon, 1998).

We also note the importance of this company in containing the advantages of companies of persons, in terms of the small number of partners, not exceeding the exchange of shares without restrictions, and the advantages of the joint stock company in terms of determining the value of office shares, as well as not dissolving them according to personal considerations, which has made them more widespread in the economic field compared to other types, but they often take a medium size due to the limited partners in them. Therefore, this area has been confronted with its transformation into joint stock companies in order to increase its capital, and since this process has been permitted by Iraqi commercial law, public institutions of local communities will enter: companies with limited liability. 


\section{Stock Corporation}

A joint stock company, or money company, is a company made up of a group of people who offer shares in their capital in the form of shares.

The value of the latter is equal and tradable and is purchased by the shareholder at the time of incorporation or by the IPO, the shareholder or partner, who bears the loss only in the amount of the shares in which he participates, i.e., the liability is limited by the value or amount of these shares. Partners are interviewed in the form of dividends, if realized. So, equity returns change as the results of the organization change, and do not represent a fixed burden.

Stock trading is also carried out on secondary financial markets on the exchanges, as its market prices change according to the changes in the activity of the institution and its results, and thus its popularity. The value of these shares may also change by the high value of the company's assets when revalued, these shares guarantee the partner to contribute to the management of the institution, by attending the general assemblies of shareholders and voting on decisions, but because of their many large shareholders, usually the few shareholders do not attend meetings.

All of this may be determined "within the company's founding law at the lower share, whose owner can vote, and the institution is managed by the board of directors chosen by the Shareholders' Association, headed by the appointed director: whether he is a shareholder, or he is an outsider" (Wadi Adon, 1998).

The importance of this company lies in the formation of its capital, and in the possibility of recruiting significant capital after the agreement between the founders who provide a certain part of the capital, and then put the rest to the public offering, as the small value of the shares makes small savers of all degrees buy these shares. Therefore, the need for a comprehensive and comprehensive review of the current financial and financial resources sectors is a key factor in the development of the country's financial system (Wadi Adon, 1998).

Based on all these advantages, these companies have occupied a wide range of economic-sports activity, particularly in capitalist countries, with a ratio of more than $70 \%$. Of the total mainly industrial enterprises and wholesale businesses.

While their number in the agricultural sector is declining due to its nature, these institutions are the most important economic aid in driving economic growth in capitalist countries from the end of the 19th century to the present, covering most of the economic activities in these countries: either by direct action or by indirect influence, despite the presence of state or public institutions that also play an important role.

\section{CONCLUSION}

Sports clubs are the backbone of the national sports formation in any country in the world, and any organization, whatever it may be, can only bear fruit, unless sports clubs are properly and accurately organized, enabling them to carry out their sports and educational mission, to the fullest possible extent.

Therefore, the Sports Club has defined the youth and sports law as a body formed by a group of individuals that aims to form the personality of young people in an integrated way, in terms of social, health, psychological, intellectual and spiritual; by spreading sports and social education, instilling a spirit of nationalism among young members, providing the right conditions for the development of their talents, as 
well as creating means and means to fill the leisure time for members; in order to stitching the central administration.

In our modern day, the club has a deeper message to achieve, and a greater goal to be achieved; it is a school with its own programmes and systems, and it is actively involved with various organs of the State in the education of young people and the care of young people.

Therefore, real sports clubs are the practical means of applying modern sports philosophy based on sound social principles, and in accordance with the principles and theories of psychological educational thesis, and this can only be achieved if they draw up their policies and plans their programmes, by investing economic institutions in sports clubs.

Based on all of the above, investment is an act aimed at increasing the capital of the individual or private economic institutions, or increasing its resources by operating or exploiting its money in a sports project as a sports institution: a sports club, for example, for investment, through the means available in this club; for a purely commercial purpose: as one of the basic means of implementing the sports development programme;

1. The rights of advertising and advertising.

2. Television marketing.

3. Marketing the sports and social establishment of the club.

1. Marketing services to the internal and external audiences.

2. Interest in registering the club's website.

3. Attention to the opening of fitness and sports centres for all to practice.

4. The work of a sports guide in which he provides information about the club and its development and achievements.

5. Attention to encrypting matches for the club, to increase the popularity of the matches.

6. Attention to the provision of memorials to viewers, such as: (stadium maps, star pictures, fixtures.... etc.).

7. Attention to the work of periodic studies of the services provided by the club.

\section{REFERENCES}

Abdel Ati, K. (2001). Proposed methods of marketing tournaments in the Arab Republic of Egypt, unpublished master's thesis, Faculty of Physical Education, Helwan University, p. 67.

Abdullah Al-Bahout, K. (2002). Deep Ignorance in Marketing Alphabets, 1st ed., Dar Al Safaa Printing, Publishing and Distribution, Amman, p. 22.

Adel, A. (2007). Marketing in Sports, 1st ed., Dar al-Book For Printing, Publishing and Distribution, Baghdad University, Baghdad, p. 28.

Ahmed Al-Shafei, H., \& Abdel Moneim, A. (2002). Sports Marketing and Investment strategy in sports institutions in light of contemporary global economic transformations, 1st ed., Al Wafa Printing and Publishing House, Cairo, p. 46.

Ahmed Shibli, S. (2003). Department of Sports Rights Marketing in First Class Clubs in the Arab Republic of Egypt, published research in: 8th International Scientific Conference for The Sciences of Physical and Sports Education, Faculty of Sports Education for Boys, Alexandria University, p. 78.

Al-Din Badawi, E. (1994). Investing time in the management of sports bodies, 1st ed., Dar al-Nahda AlArabiya Press, Cairo, , p. 26.

Al-Din Badawi, E., \& Amiri, K. (1992). The Scientific Development of the Concept of Sport, 1st ed., Al Shabab Printing, Publishing and Distribution House, Cairo, p. 226. 
Al-Qurbuti, M. (2001). Principles of Modern Marketing, 1st ed., Safaa Publishing and Distribution House, Amman, p. 23.

Al-Zugheer, H. (1998). Trends of Jordanian Industrial Companies towards Supporting Sports Activities and Their Preferred Support, Unpublished Master's Thesis - University of Jordan, , p. 18.

Aqili, O. (1994). Principles of Marketing, 1st ed., Zahran Publishing and Distribution House, Amman, p. 91.

Habib, R. (1994). Marketing, 1st ed., Dar al-Book, Jeddah, p. 43.

Jamil Al-Rubadi, K. (2003). Sports in the Labyrinths of Politics, 1st ed., Wael Publishing House, Amman, p. 20.

Saleh Al-Hanawi, M. (1984). Marketing Department, 1st ed., House of Egyptian Societies, Cairo, p. 31.

Samir, A. (1999). Management of Sports Bodies (Modern Theories and Their Application), 2nd ed., Knowledge Project, Cairo, p. 39.

Sari Ahmed, H., \& Suha Adeeb, I. Marketing methods through sports activities as seen by businessmen in Jordan, Scientific Journal of Physical Education and Sports, 2, Helwan University, p. 85.

Wadi Adon, N. (1998). Enterprise Economy, 1st ed., General House of Mohammedia, Algeria, p. 102.

Yasser Al Sabah, S. (2010). The Reality of Sports Sponsorship at The Premier League (A) Football Clubs and their Impact on The Level of Sports Achievement, Unpublished Master's Thesis - Yarmouk University, Amman, p. 11. 